\title{
Penggunaan Regresi Linear Berganda untuk Menganalisis Pendapatan Petani Kelapa Studi Kasus: Petani Kelapa Di Desa Beo, Kecamatan Beo Kabupaten Talaud
}

\author{
Margaretha G. Mona ${ }^{1}$, John S. Kekenusa ${ }^{2}$, Jantje D. Prang ${ }^{3}$ \\ ${ }^{1}$ Program Studi Matematika, FMIPA, UNSRAT Manado, gebbymona52@gmail.com \\ ${ }^{2}$ Program Studi Matematika, FMIPA, UNSRAT Manado, johnskekenusa@yahoo.com \\ ${ }^{3}$ Program Studi Matematika, FMIPA, UNSRAT Manado, jantjeprang@yahoo.com
}

\begin{abstract}
Abstrak
Desa Beo merupakan salah satu desa yang ada di Kabupaten Kepulauan Talaud dimana sebagian besar masyarakat Desa Beo adalah petani yang memiliki tanaman kelapa yang merupakan sumber pendapatan yang sangat penting. Tujuan penelitian ini adalah untuk mengetahui seberapa besar pengaruh variabel yang telah dipilih terhadap pendapatan petani kelapa di desa Beo dengan menggunakan analisis regresi linier berganda. Dalam penelitian ini digunakan data primer, dengan simple random sampling sebagai teknik pengambilan sampel. Pengujian hipotesis dengan menggunakan uji $\mathrm{F}$ diketahui bahwa jumlah produksi buah kelapa, biaya, luas lahan, jumlah pohon kelapa dan banyaknya anggota keluarga secara bersama-sama memiliki pengaruh terhadap pendapatan petani kelapa. Variabel yang memiliki pengaruh yang signifikan terhadap pendapatan petani kelapa yaitu jumlah produksi buah kelapa dan biaya dan nilai koefisien yang dihasilkan adalah 0,907 atau 90,7 persen.
\end{abstract}

Kata kunci: Analisis Regresi Linear Berganda, Pendapatan Petani Kelapa.

\section{The Use of Multivariate Linear Regression to Analyse Income of Coconut Farmer Case Study : Coconut Farmer in Beo Village, Beo Sub-District, Talaud Regency}

\begin{abstract}
Beo village is one of the villages in the Talaud Islands where most of the Beo villagers are farmers who have coconut plants that very important source of income. The purpose of this study was to determine how much influence of the variables that have been on the income of coconut farmers in the Beo village using multiple linear regression analysis. This study used primary data, with simple random sampling as the sampling technique. Hypothesis testing using $F$ test so that it is known that the amount of coconut production, costs, land area, number of coconut trees and many family members together have an influence on the income of coconut farmers. Variables that have a significant effect on the income of coconut farmers is the amount of coconut production and the costs and the resulting coefficient is 0,907 or 90,7 percent.
\end{abstract}

Keywords: Multivariate Linear Regression, Income Coconut Farmer.

\section{Pendahuluan}

Indonesia merupakan salah satu Negara agraris yang kehidupan perekonomiannya tidak bisa lepas dari sektor pertanian. Hal ini karena sektor pertanian, masih tetap memegang peranan penting yakni sebagai penyedia bahan pangan bagi seluruh masyarakat, serta menopang pertumbuhan industri dalam hal penyediaan bahan baku industri. Sub sektor perkebunan, merupakan bagian dari sektor pertanian yang memberikan konstribusi besar dalam perekonomian Indonesia. Secara umum tanaman perkebunan mempunyai peranan yang besar, terutama dalam penyediaan lapangan kerja, pendapatan dari ekspor dan sumber pertumbuhan ekonomi. 
Tanaman kelapa dalam perekonomian Indonesia merupakan salah satu komoditi strategis karena perannya yang sangat besar, baik sebagai sumber pendapatan maupun sumber bahan baku industri. Tanaman kelapa merupakan tanaman serbaguna yang mempunyai nilai ekonomi tinggi. Seluruh bagian pohon kelapa dapat dimanfaatkan untuk kepentingan manusia. Hampir seluruh bagian pohon dari akar, batang, daun, hingga buahnya dapat digunakan untuk kebutuhan kehidupan manusia sehari-hari.

Adapun masalah dalam penelitian ini yaitu :Apakah ada pengaruh yang signifikan terhadap pendapatan petani kelapa dari jumlah produksi buah kelapa, biaya, jumlah pohon kelapa, luas lahan dan jumlah anggota keluarga secara bersama-sama; Dari kelima variabel bebas di atas, variabel manakah yang memiliki pengaruh yang dominan terhadap pendapatan petani kelapa dan berapah besar pengaruh dari variabel tersebut terhadap pendapatan petani kelapa.

Tujuan penelitian ini yaitu menganalisis jumlah produksi buah kelapa, biaya, jumlah pohon kelapa, luas lahan dan jumlah anggota keluarga secara bersama-sama apakah ada pengaruh signifikan terhadap pendapatan petani kelapa serta Mengetahui variabel bebas manakah yang memiliki pengaruh yang dominan terhadap pendapatan petani kelapa dan berapa besar pengaruh dari variabel tersebut terhadap pendapatan petani kelapa.

\section{Analisis Regresi Linear Berganda}

Analisis yang memiliki variabel bebas lebih dari satu disebut analisis regresi linier berganda. Teknik regresi linier berganda digunakan untuk mengetahui ada tidaknya pengaruh signifikan dua atau lebih variabel bebas $\left(X_{1}, X_{2}, X_{3}, \ldots \ldots ., k\right)$ terhadap variabel terikat (Y).Model regresi linier berganda untuk populasi dapat ditunjukkan sebagai berikut [1] :

$$
Y=\beta_{0}+\beta_{1} X_{1}+\beta_{2} X_{2}+\cdots+\beta_{n} X_{n}+e
$$

Model regresi linier berganda untuk populasi diatas dapat ditaksir dengan model regresi linier berganda untuk sampel, yaitu :

$$
\begin{aligned}
& \hat{Y}=b_{0}+b_{1} X_{1}+b_{2} X_{2}+\cdots+b_{k} X_{k} \\
\text { dengan : } \quad \hat{Y} & =\text { nilai penduga bagi variabel Y } \\
b_{0} & =\text { dugaan bagi parameter konstanta } \\
b_{1}, b_{2}, \ldots \ldots \ldots & b_{k}=\text { dugaan bagi parameter konstanta } \beta_{1}, \beta_{2, \ldots \ldots . . .} \beta_{k} \\
X & =\text { variabel bebas. }
\end{aligned}
$$

\subsection{Uji Asumsi Klasik}

\subsubsection{Uji Heteroskedastisitas}

Uji heteroskedastisitas dilakukan untuk menguji apakah dalam sebuah model regresi terjadi ketidaksamaan varians residual dari satu pengamatan ke pengamatan yang lain tetap, maka disebut heteroskedastisitas [2].

\subsubsection{Uji Normalitas}

Tujuan uji normalitas adalah untuk menguji apakah dalam sebuah model regresi, variabel terikat dan variabel bebas atau keduanya mempunyai distribusi normal ataukah tidak. Model regresi yang baik adalah distribusi data normal atau mendekati normal. Deteksi normalitas dilakukan dengan melihat grafik Normal Probability Plot [3].

\subsection{Metode Kuadrat Terkecil}

Salah satu prosedur pendugaan model untuk regresi linier berganda adalah dengan prosedur Least Square (kuadrat terkecil). Konsep dari metode least Square adalah menduga koefisien regresi $(\beta)$ dengan meminimumkan kesalahan (error) [4].

\subsection{Koefisien Determinasi}

Koefisien determinasi ganda (coefficient of multiple determination) dinotasikan dengan $R^{2}$, didefinisikan sebagai berikut:

$$
R^{2}=\frac{J K R}{J K T}=1-\frac{J K G}{J K T}
$$


$R^{2}$ akan bernilai 0 bila semua $b_{k}=0 . R^{2}$ akan bernilai 1 bila semua amatan Y berada tepat pada permukaan respon suaiannya, dengan kata lain $Y_{i}=\hat{Y}_{i}$ [5].

$\boldsymbol{R}_{\boldsymbol{a d j}}^{\mathbf{2}}$ adalah penyesuaian dari $\boldsymbol{R}^{\mathbf{2}}$. Nilai $\boldsymbol{R}_{\boldsymbol{a d j}}^{\mathbf{2}}$ ditentukan dengan rumus :

$$
R_{a d j}^{2}=1\left(\frac{n-1}{n-k}\right) \frac{J K G}{J K T}
$$

dengan $\mathrm{n}=$ jumlah amatan

Nilai $R_{a d j}^{2}$ hanya akan naik jika nilai (n-k)JKG turun, karena (n-1) JKT tetap. Model yang baik memiliki $R_{a d j}^{2}$ yang besar [6].

\section{Metodologi Penelitian}

Data yang digunakan adalah data primer dari wawancara langsung berdasarkan daftar pertanyaan terhadap petani kelapa di Desa Beo Kecamatan Beo Kabupaten Kepulauan Talaud.

\subsection{Waktu dan Tempat Penelitian}

Penelitian ini dilakukan dari bulan Mei sampai dengan Juli tahun 2015. Tempat penelitian dilakukan di Desa Beo Kecamatan Beo Kabupaten Kepulauan Talaud.

\subsection{Metode Pengambilan Sampel}

Teknik pengambilan sampel yang digunakan adalah simple random sampling. Populasi yang dijadikan objek penelitian adalah petani kelapa di desa Beo yang berjumlah 50 orang. Jumlah sampel yang ditentukan dari banyaknya populasi petani kelapa di Desa Beo menggunakan metode Slovin, yaitu :

$$
n=\frac{N}{1+N \cdot e^{2}}
$$

dimana: $\mathrm{n}=$ jumlah sampel

$\mathrm{N}=$ jumlah populasi

$\mathrm{e}=$ persen kelonggaran ketidaktelitian $(0,05)$

sehingga diperoleh hasil

$$
n=\frac{50}{1+50 \cdot 0,05^{2}}=44,4=44
$$

\subsection{Identifikasi dan Pengukuran Variabel}

Dalam penelitian ini, variabel yang diukur yaitu :

1. Jumlah Produksi Buah Kelapa $\left(\mathrm{X}_{1}\right)$ : Jumlah produksi buah kelapa yaitu besarnya produksi buah kelapa (kopra) yang diukur dalam $\mathrm{Kg}$.

2. Biaya $\left(\mathrm{X}_{2}\right)$ : Biaya yaitu biaya yang dikeluarkan oleh petani untuk tenaga kerja yang dipekerjakan sampai pada proses produksi.Menggunakan satuan rupiah (Rp).

3. Jumlah Pohon Kelapa $\left(\mathrm{X}_{3}\right)$ : Jumlah pohon kelapa yaitu banyaknya pohon kelapa yang berproduksi.

4. Luas Lahan $\left(\mathrm{X}_{4}\right)$ : Luas lahan merupakan luas lahan petani kelapa yang digunakan untuk menanam pohon kelapa yang diukur dengan satuan $m^{2}$.

5. Jumlah Anggota Keluarga $\left(\mathrm{X}_{5}\right)$ : Jumlah anggota keluarga merupakan semua anggota keluarga yang tinggal dalam satu rumah yang ikut dalam usahatani kelapa.

6. Pendapatan Petani Kelapa (Y) : Hasil yang diperoleh dari produksi usahatani dalam satu kali masa panen, menggunakan satuan rupiah (Rp). 


\subsection{Analisis Data}

Analisis data yang digunakan dalam penelitian ini adalah Regresi linier berganda. Model ini dipilih untuk mengetahui seberapa besar pengaruh variabel bebas terhadap variabel terikat baik secara parsial maupun bersama-sama. Sebelum model regresi digunakan untuk menguji hipotesis, maka terlebih dahulu dilakukan :

1. Pengujian asumsi klasik

Dalam penelitian ini uji asumsi klasik yang dilakukan adalah :

- Uji multikolinieritas

- Uji heteroskedastisitas

- Uji normalitas

2. Pengujian Hipotesis

Apabilah syarat untuk ditelitinya suatu model regresi telah terpenuhi semua, maka langkah selanjutnya untuk mengetahui diterima atau tidaknya hipotesis yang diajukan dalam penelitian ini, dilakukan analisis data dengan :

- Uji F

- Uji T

\section{Hasil dan Pembahasan}

\subsection{Uji Normalitas}

Hasil uji normalitas dengan metode grafik dapat dilihat pada gambar 1 berikut ini.

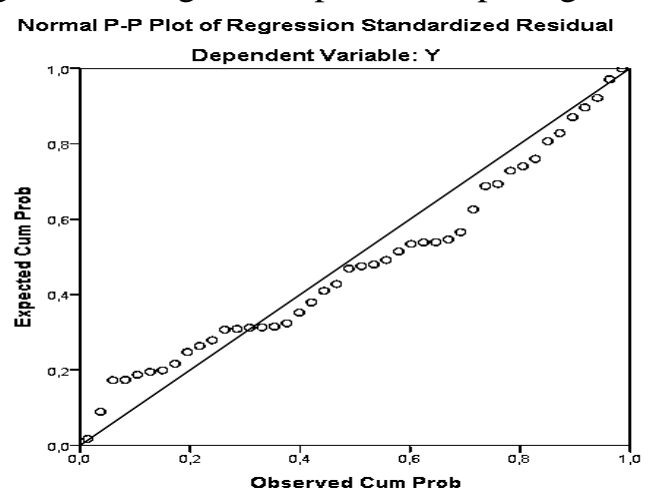

Gambar 1. Hasil Uji Normalitas

Pada gambar 1 dapat dilihat bahwa grafik normal probability plot menunjukkan pola grafik yang normal. Hal ini terlihat dari titik yang menyebar di sekitar grafik normal dan penyebarannya mengikuti garis diagonal.

Hasil uji normalitas dengan metode statistik dapat dilihat pada tabel 1 uji One Sample Kolmogorov Smirnov.

Tabel 1. Hasil Uji One Sample Kolmogorov Smirnov

\begin{tabular}{|ll|l|}
\hline & & Unstandardized \\
Residual
\end{tabular}

a. Test distribution is Normal. b. Calculated from data.

Dari output diatas dapat diketahui bahwa nilai signifikansi sebesar 0,397. Karena signifikansi lebih dari 0,05 $(0,397>0,05)$, maka nilai residual tersebut telah normal. Oleh karena itu dapat disimpulkan bahwa model regresi layak dipakai karena memenuhi asumsi normalitas. 


\subsection{Uji Koefisien Regresi Linier Berganda}

\subsubsection{Uji Simultan (Uji F)}

Langkah-langkah pengujiannya adalah sebagai berikut :

a. Menentukan Formulasi Hipotesis

- $H_{0}: b_{i}=0$,artinya variabel jumlah produksi buah kelapa $\left(X_{1}\right)$, biaya $\left(X_{2}\right)$, jumlah pohon kelapa $\left(X_{3}\right)$, luas lahan $\left(X_{4}\right)$, dan jumlah anggota keluarga $\left(X_{5}\right)$ tidak mempunyai pengaruh yang signifikan secara bersama terhadap variabel pendapayan kelapa $(Y)$.

- $H_{0}: b_{i} \neq 0$, artinya variabel jumlah produksi buah kelapa $\left(X_{1}\right)$, biaya $\left(X_{2}\right)$, jumlah pohon kelapa $\left(X_{3}\right)$, luas lahan $\left(X_{4}\right)$, dan jumlah anggota keluarga $\left(X_{5}\right)$ mempunyai pengaruh yang signifikan secara simultan terhadap variabel pendapayan kelapa $(Y)$.

b. Menentukan derajat kepercayaan $95 \%(\alpha=0,05)$

c. Menentukan signifikansi

- Nilai signifikasi $(P V a l u e)<0,05$ maka $H_{0}$ ditolak dan $H_{1}$ diterima

- Nilai signifikasi $(P$ Value $)>0,05$ maka $H_{0}$ diterima dan $H_{1}$ ditolak

d. Membuat kesimpulan

- Bila (PValue $)<0,05$ maka $H_{0}$ ditolak dan $H_{1}$ diterima. Artinya independent variable secara simultan (bersama-sama) mempengaruhi dependent variable.

- Bila $(P$ Value $)>0,05$ maka $H_{0}$ diterima dan $H_{1}$ ditolak. Artinya independent variable secara simultan (bersama-sama) tidak mempengaruhi dependent variable.

Hasil uji F pada penelitian dapat dilihat pada tabel 2 berikut ini :

Tabel 2. Hasil Uji F

ANOVA $^{\mathrm{a}}$

\begin{tabular}{|ll|l|l|l|l|l|}
\hline Model & & Sum of Squares & Df & Mean Square & F & Sig. \\
\hline \multirow{4}{*}{1} & Regression & 44727185575680,720 & 5 & 8945437115136,145 & 85,075 &, $000^{\mathrm{b}}$ \\
& Residual & 3995627333410,177 & 38 & 105148087721,320 & & \\
& Total & 48722812909090,900 & 43 & & & \\
\hline
\end{tabular}

a. Dependent Variable: Y b. Predictors: (Constant), X5, X4, X1, X3, X2

Dari hasil uji $\mathrm{F}$ pada penelitian ini, didapatkan nilai $\mathrm{F}$ hitung sebesar 85,075 dengan angka signifikansi sebesar 0,000. Dengan tingkat signifikansi 95\% $(\alpha=0,05)$. Angka signifikansi sebesar $0,000<0,005$. Atas dasar perbandingan tersebut, maka $H_{0}$ ditolak atau berarti variabel jumlah produksi buah kelapa $\left(X_{1}\right)$, biaya $\left(X_{2}\right)$, jumlah pohon kelapa $\left(X_{3}\right)$, luas lahan $\left(X_{4}\right)$, dan jumlah anggota keluarga $\left(X_{5}\right)$ mempunyai pengaruh yang signifikansi secara bersama-sama terhadap variabel pendapatan petani kelapa dengan persamaan sebagai berikut :

$Y=159578,804+821,689 X_{1}-0,235 X_{2}+1451,619 X_{3}+15,735 X_{4}+14768,170 X_{5}$

\subsubsection{Uji t}

Hasil uji t pada penelitian ini dapat dilihat pada tabel 3 berikut ini :

Tabel 3. Hasil Uji t

Coefficients $^{\mathrm{a}}$

\begin{tabular}{|c|c|c|c|c|c|c|c|c|}
\hline \multirow{2}{*}{\multicolumn{2}{|c|}{ Model }} & \multicolumn{2}{|c|}{ Unstandardized Coefficients } & \multirow{2}{*}{\begin{tabular}{|l}
$\begin{array}{l}\text { Standardized } \\
\text { Coefficients }\end{array}$ \\
Beta \\
\end{tabular}} & \multirow[t]{2}{*}{$\mathrm{t}$} & \multirow[t]{2}{*}{ Sig. } & \multicolumn{2}{|c|}{ Collinearity Statistics } \\
\hline & & B & Std. Error & & & & Tolerance & VIF \\
\hline \multirow{6}{*}{1} & (Constant) & 159578,804 & 163164,714 & & ,978 & ,334 & & \\
\hline & $\mathrm{X} 1$ & 821,689 & 281,074 & 1,502 & 2,923 & ,006 & ,078 & 12,836 \\
\hline & $\mathrm{X} 2$ &,- 235 & , 105 & $-1,142$ & $-2,246$ &, 031 & 080 & 12,566 \\
\hline & X3 & 1451,619 & 997,654 & ,499 & 1,455 & , 154 & , 175 & 5,708 \\
\hline & $\mathrm{X} 4$ & 15,735 & 22,813 & ,287 & 690 & ,495 & ,119 & 8,399 \\
\hline & $\mathrm{X} 5$ & 14768,170 & 39452,568 & ,058 & 374 &, 710 & 854 & 1,170 \\
\hline
\end{tabular}

a. Dependent Variable: Y 
Berdasarkan tabel 3, maka hasil uji t pada penelitian ini dapat dijelaskan sebagai berikut :

1. Jumlah Produksi Buah Kelapa $\left(X_{1}\right)$

Hipotesis Jumlah Produksi Buah Kelapa adalah :

- $H_{0}: \beta_{1}=0$, jumlah produksi buah kelapa tidak mempunyai pengaruh yang signifikan secara parsial terhadap pendapatan petani kelapa.

- $H_{1}: \beta_{1} \neq 0$, jumlah produksi buah kelapa mempunyai pengaruh yang signifikan secara parsial terhadap pendapatan petani kelapa.

Hasil pengujian dengan SPSS diperoleh untuk variabel $X_{1}$ diperoleh nilai $\mathrm{t}$ hitung $=2,923$ dengan tingkat signifikansi 0,006 . Dengan menggunakan batas signifikansi 0,05 , nilai signifikansi tersebut lebih kecil dari taraf $5 \%$ yang berarti $H_{0}$ ditolak dan $H_{1}$ diterima. Artinya jumlah produksi buah kelapa mempunyai pengaruh terhadap pendapatan petani kelapa.

2. Biaya $\left(X_{2}\right)$

Hipotesis Biaya adalah :

- $H_{0}: \beta_{1}=0$, biaya tidak mempunyai pengaruh yang signifikan secara parsial terhadap pendapatan petani kelapa.

- $H_{1}: \beta_{1} \neq 0$, biaya mempunyai pengaruh yang signifikan secara parsial terhadap pendapatan petani kelapa.

Hasil pengujian dengan SPSS diperoleh untuk variabel $X_{2}$ diperoleh nilai $\mathrm{t}$ hitung $=-2,246$ dengan tingkat signifikansi 0,031. Dengan menggunakan batas signifikansi 0,05 , nilai signifikansi tersebut lebih kecil dari taraf $5 \%$ yang berarti $H_{0}$ ditolak dan $H_{1}$ diterima. Artinya biaya mempunyai pengaruh terhadap pendapatan petani kelapa.

3. Jumlah Pohon Kelapa $\left(X_{3}\right)$

Hipotesis Jumlah Pohon Kelapa adalah :

- $H_{0}: \beta_{1}=0$, jumlah pohon kelapa tidak mempunyai pengaruh yang signifikan secara parsial terhadap pendapatan petani kelapa.

- $H_{1}: \beta_{1} \neq 0$, jumlah pohon kelapa mempunyai pengaruh yang signifikan secara parsial terhadap pendapatan petani kelapa.

Hasil pengujian dengan SPSS diperoleh untuk variabel $X_{3}$ diperoleh nilai t hitung $=1,455$ dengan tingkat signifikansi 0,154. Dengan menggunakan batas signifikansi 0,05 , nilai signifikansi tersebut lebih besar dari taraf $5 \%$ yang berarti $H_{0}$ diterima dan $H_{1}$ ditolak. Artinya jumlah pohon kelapa tidak mempunyai pengaruh terhadap pendapatan petani kelapa.

4. Luas Lahan $\left(X_{4}\right)$

Hipotesis Luas Lahan adalah :

- $H_{0}: \beta_{1}=0$, luas lahan tidak mempunyai pengaruh yang signifikan secara parsial terhadap pendapatan petani kelapa.

- $H_{1}: \beta_{1} \neq 0$, luas lahan mempunyai pengaruh yang signifikan secara parsial terhadap pendapatan petani kelapa.

Hasil pengujian dengan SPSS diperoleh untuk variabel $X_{4}$ diperoleh nilai t hitung $=0,690$ dengan tingkat signifikansi 0,495. Dengan menggunakan batas signifikansi 0,05 , nilai signifikansi tersebut lebih besar dari taraf $5 \%$ yang berarti $H_{0}$ diterima dan $H_{1}$ ditolak. Artinya luas lahan tidak mempunyai pengaruh terhadap pendapatan petani kelapa.

5. Jumlah Anggota Keluarga $\left(X_{5}\right)$

Hipotesis Jumlah Anggota Keluarga adalah :

- $H_{0}: \beta_{1}=0$, jumlah anggota keluarga tidak mempunyai pengaruh yang signifikan secara parsial terhadap pendapatan petani kelapa.

- $H_{1}: \beta_{1} \neq 0$, jumlah anggota keluarga mempunyai pengaruh yang signifikan secara parsial terhadap pendapatan petani kelapa.

Hasil pengujian dengan SPSS diperoleh untuk variabel $X_{5}$ diperoleh nilai t hitung $=0,374$ dengan tingkat signifikansi 0,710 . Dengan menggunakan batas signifikansi 0,05 , nilai signifikansi tersebut lebih besar dari taraf $5 \%$ yang berarti $H_{0}$ diterima dan $H_{1}$ ditolak. Artinya jumlah anggota keluarga tidak mempunyai pengaruh terhadap pendapatan petani kelapa. 


\subsection{Analisis Regresi Linier Berganda}

Dari hasil regresi dengan menggunakan program SPSS, maka didapatkan koefisien regresi yang dapat dilihat pada tabel 4 .

Tabel 4. Hasil Uji Regresi (Koefisien Regresi)

Coefficients $^{\mathrm{a}}$

\begin{tabular}{|ll|l|l|l|l|l|}
\hline \multicolumn{2}{|l|}{ Model } & \multicolumn{2}{|l|}{ Unstandardized Coefficients } & $\begin{array}{l}\text { Standardized } \\
\text { Coefficients }\end{array}$ & $\mathrm{t}$ & \multirow{2}{*}{ Sig. } \\
\cline { 3 - 5 } & & $\mathrm{B}$ & Std. Error & Beta & & \\
\hline \multirow{2}{*}{1} & (Constant) & 110373,477 & 115395,677 & &, 956 &, 344 \\
& X1 & 680,423 & 246,050 & 1,244 & 2,765 &, 008 \\
& X2 &,- 214 &, 093 & $-1,043$ & $-2,318$ &, 025 \\
\hline
\end{tabular}

a. Dependent Variable: $\mathrm{Y}$ berikut :

Berdasarkan tabel diatas maka didapatkan persamaan regresi linier berganda sebagai

$$
Y=110373,477+680,423 X_{1}-0,214 X_{2}
$$

Persamaan diatas dapat dijelaskan sebagai berikut :

1. Jika jumlah produksi buah kelapa $\left(X_{1}\right)$ bertambah 1 buah maka pendapatan petani akan meningkat sebesar 680,42.

2. Jika biaya $\left(X_{2}\right)$ naik sebesar Rp 1000,00 maka pendapatan petani akan turun sebesar Rp 214,00 .

Sedangkan koefisien determinasi dari persamaan diatas dapat dilihat pada tabel5.

Tabel 5. Hasil Uji Koefisien Determinasi

Model Summary ${ }^{\mathrm{b}}$

\begin{tabular}{|l|l|l|l|l|l|l|}
\hline Model & $\mathrm{R}$ & R Square & $\begin{array}{l}\text { Adjusted } \\
\text { Square }\end{array}$ & $\begin{array}{l}\text { Std. Error of the } \\
\text { Estimate }\end{array}$ & Durbin-Watson \\
\hline 1 &, $955^{\mathrm{a}}$ &, 911 &, 907 & $325.024,914$ & 2,221 \\
\hline
\end{tabular}

a. Predictors: (Constant), X2, X1

b. Dependent Variable: Y

Dapat dikatakan bahwa 90,7 \% keragaman dari pendapatan petani kelapa dapat dijelaskan oleh

$$
\mathrm{Y}=\mathbf{1 1 0 3 7 3 , 4 7 7 + 6 8 0 , 4 2 3} X_{1}-0,214 X_{2}
$$

\section{Kesimpulan}

Pada hasil penelitian dengan pengujian hipotesis menggunakan uji $\mathrm{F}$ diketahui bahwa jumlah produksi buah kelapa $\left(X_{1}\right)$, biaya $\left(X_{2}\right)$, jumlah pohon kelapa $\left(X_{3}\right)$, luas lahan $\left(X_{4}\right)$, dan jumlah anggota keluarga $\left(X_{5}\right)$ secara bersama-sama berpengaruh terhadap pendapatan petani kelapa. Hal ini ditunjukkan dari nilai $\mathrm{F}$ hitung sebesar 85,075 dengan angka signifikansi sebesar 0,000 . Nilai koefisien determinasi ganda $\left(R^{2}\right)$ yang dihasilkan adalah 0,918 dan nilai $R_{a d j}^{2}$ adalah 0,907 atau $90,7 \%$.

Pada hasil analisis regresi linier berganda diperoleh bahwa yang memiliki pengaruh terhadap pendapatan petani kelapa adalah variabel jumlah produksi buah kelapa (X1) dan biaya (X2) dengan persamaan sebagai berikut :

$$
Y=110373,477+680,423 X_{1}-0,214 X_{2}
$$

Berdasarkan persamaan diatas, variabel jumlah produksi buah kelapa memiliki nilai koefisien regresi sebesar 680,423 dengan nilai signifikansi 0,000. Sedangkan variabel biaya memiliki nilai koefisien regresi sebesar 0,214 dengan nilai signifikansi sebesar 0,000. Nilai koefisien determinasi ganda $\left(R^{2}\right)$ yang dihasilkan adalah 0,918 dan nilai $R_{a d j}^{2}$ adalah 0,907 atau $90,7 \%$. 


\section{Daftar Pustaka}

[1] Supranto, J. 2004. Analisis Multivariat Arti dan Interpretasi. Rineka Cipta. Jakarta.

[2] Santoso, S. 2000. Latihan SPSS Statistik Parmetik. Gramedia, Jakarta.

[3] Ghozali, I. 2005. Aplikasi Analisis Multivariat dengan program SPSS, Badan Penerbit Universitas Diponegoro, Semarang.

[4] Draper, N. R, dan S. Harry, 1992. Analisis Regresi Terapan. Gramedia Pustaka Utama, Jakarta.

[5] Hatidja, D. 2006. Bahan Ajar Analisis Regresi. Jurusan Matematika FMIPA UNSRAT. Manado.

[6] Hanun, H. 2011. Perbandingan Metode Stepwise, Best Subset Regression, dan Fraksi Dalam Pemilihan Model Regresi Berganda Terbaik. Jurnal Penelitian Sains. (14)2 : 1-6. 